\title{
Detouring to Grafton: The Sydney Botanic Gardens and the Making of an Australian Urban Aesthetic
}

\author{
JODI FRAWLEY
}

For the last seventy-five years Grafton has celebrated the Jacaranda Festival in late October. The festival commences in the town square with the crowning of the Jacaranda Queen and ends a week later with a parade through the town. The event is now a major regional tourist attraction that aims to bring locals and visitors together to celebrate everything purple. During this week one can attend the jacaranda children's party, the jacaranda maypole dancing, the jacaranda choral service or the jacaranda organ recital. Local businesses are encouraged to compete in the decorated window displays competition and everyone can join in the procession. The festival pays homage to the extraordinary display of beautiful jacaranda blooms which carpet the city during this time. The festival was inaugurated in 1935 when the slow growing jacarandas planted in the late nineteenth and early twentieth centuries were coming to maturity.

The proactive pursuit of this street tree planting by local residents of Grafton locates them as part of a broader movement seeking to enact change in order to civilise the city. One agent of change linking Grafton to this broader movement was the Sydney Botanic Gardens. Unlike the Grafton council, who planted and maintained trees, the role of this institution was to disseminate both information about street trees and seedlings and young trees to be planted into streetscapes. The Sydney Botanic Gardens collected plants, plant material and plant information from many other global locations into the herbarium, library and gardens at the Farm Cove site adjacent to Sydney's central business district. This material about street trees made its way into these centres as part of the larger processes of botanical exchanges and transfers.

The role of the Gardens over the nineteenth century was to translate these resources for useful application into settlement problems and issues. For example, pastoralism was one of the key industries that needed to understand how to adapt Australian environments for domesticated animals, especially cattle, sheep and horses. In line with these needs, the Sydney Botanic Gardens 
researched the adaptability of various indigenous and exotic grasses and fodder plants for use in local conditions. Grasses were sent there from the United States Bureau of Plant Industry to assess their usefulness to Australian farms. On the other hand the Chief Inspector of Stock stationed at Bourke in Western New South Wales sent grasses to the herbarium for identification. This was a way of providing an important service for people learning about pastoralism under Australian conditions. Eventually in 1915, the Sydney Botanic Gardens had four staff working in agrostology, the study of grasses. Additionally they published lists of weeds of New South Wales and distributed lists of plants that were noxious to stock. When the prickly pear, originally introduced as a fodder plant, became an invasive problem, the Sydney Botanic Gardens was a key site for gathering and analysing information from America, Germany, and South Africa about this plant, such that this knowledge could be utilised in the Australian context.

This made the Sydney Botanic Gardens a hub, or a node in a network that participated in moving botanical knowledges around the world. However, this system was not restricted to matters of economy, or of pure science. Plants were also introduced for ornamental and aesthetic reasons. In the newly formed towns of the mid nineteenth century the new streets were originally bare of any decorative effect. This was identified as a problem that could be resolved through introducing trees into the streets. Establishing an Australian urban aesthetic relied on the very same systems of exchange as the work on fodder species. Plants, plant material and plant information regarding street trees moved through the Sydney Botanic Gardens to assist local communities enhance their urban aesthetics. Grafton was one place amongst many across New South Wales that was an active recipient of these ideas.

For the purposes of this argument Grafton is a detour; a necessarily partial account. Grafton does not represent all cities in New South Wales, but it was not unique in its introduction of street trees either. There were two distinct phases of planting of street trees in Grafton. The first dates from the 1870s until the turn of the century and saw a mixture of exotic and indigenous trees used in street environs. The second phase, from 1900 to the 1920s, favoured the introduction of a single exotic species, Jacaranda mimosifolia, for uniform-avenue planting. I will argue that both phases in street tree plantings were responses to trends in urban landscaping that were also being taken up in other parts of the world. This paper traces the way that this particular local place was connected to these global ideas through the Sydney Botanic Gardens. It provides a grounded account of the way that the Sydney Botanic Gardens was able to act as a hub of information and material culture to facilitate movement of plants, plant material 
and plant information for urban landscaping. As such it also demonstrates that local ideas played an important part in the way that these global trends were taken up in one Australian place.

By the late nineteenth century many Australian country towns had started to include trees as part of their street form. Henry Lawrence has shown the global reach of an urban aesthetic that incorporated this type of planting in his book City Trees. The cities of Europe often included street trees in metropolitan restructuring undertaken over the nineteenth century as a part of bigger projects of urban planning and change. Additionally street trees were found in many towns and cities of colonised places. This trend was not restricted to colonies of the British Empire, but also included sites under French, Dutch and Spanish influence and control (Lawrence). In North America, in the same period, pin oaks, lindens and elms were planted into Washington's avenues in the 1880s (Solotaroff). Robert Freestone links the trends for urban beautification in North America and Europe to those that developed in Australia in the second half of the nineteenth century. If, as Freestone argues, this was a matter of increased consciousness of comparative 'civic achievements and attractiveness' on an international scale, then it also follows that Australians were guided by the trends established in other places (159). However this idea needed two things to succeed in a local place like Grafton: a local advocate and access to the right types of trees.

\section{Sydney Botanic Gardens}

Botanic gardens had an important role to play in this general global trend of local street tree planting. Many of the places that introduced street trees also had access to a local botanic garden. The establishment of these places as important colonial and imperial centres mostly occurred across the nineteenth century. One of the tasks required of these places was to establish nurseries and propagation houses. This was part of their operations whether they were located in metropolitan centres or colonial outposts. Governments, whether municipal or state, required botanic gardens to provide plant stock for a variety of public functions, including city gardens and parks, beautification of civic buildings and for streets. This was never the primary work of such institutions although it was very common in many different locations. This work was done in Rockhampton Botanic Gardens in Queensland ('Rockhampton'); Peitermaritzburg Botanic Gardens in South Africa (McCracken and McCracken 78-84), and even the Royal Botanic Gardens, Kew (Desmond 181-2). In Victoria, the Melbourne Botanic Gardens supported two different phases of street tree planting in the state capital (Spencer). The seeds and plant material used in the nurseries for these purposes were ancillary to the larger exchange networks of such botanic gardens. 
Exchanging seeds and plants was one of the primary functions of nineteenth century botanic gardens. As a rule such exchanges supported the scientific work of these institutions with herbarium specimens, botanical illustrations, and wet specimens transiting across states, colonies and empires in a quest to map the botanical world. In this way material from colonial outposts was sent to Europe and material from Europe was sent to Australia. Joseph Banks saw the Royal Botanic Gardens, Kew as 'the botanical metropolis of the world' in relation to other globally located institutions (Desmond 302). In addition to these "traditional" imperial pathways, botanic gardens also exchanged material into lateral networks. India, Java, South Africa, Brazil and the United States of America also traded plants, plant material and plant information with Australia. Scientific work produced in Australia relied on flows of plants, plant material and plant information that turned their herbariums and libraries into hubs in transnational botanical exchange networks.

In addition to scientific works and reports from botanic gardens all over the world, the Sydney Botanic Gardens library also collected journals that provided detail about street planting. For example, the Journal of Horticulture and Cottage Gardener ran various series about street planting that included 'trees and shrubs for towns' (1882) 'tree planting in London' (1887) and 'town gardening' (1867). Trees such as horse chestnuts, limes, elms and oaks were recommended for planting in avenues by correspondents of the journal (KMH, 185). Other popular journals such as The Garden and The Gardeners' Chronicle were collected in the library and carried reports of these landscaping trends from Europe. In this way information and ideas about street trees were made available for Sydney Botanic Gardens staff. Many of the types of trees suggested by these journals were also included in the plant transfers from other places.

Information about streets and their trees also came from North America. The Californian Garden and Forest published articles about roadside trees that championed a range of varieties and styles including Australian eucalypts. The Sydney Botanic Gardens library also collected reports from other municipal authorities who worked in this area, including the department of parks and boulevards of the city of Detroit from 1905 to 1915 . These sorts of reports allowed Sydney staff to compare practical aspects of urban gardening and maintenance with other authorities vested with this task. In this way the library was a repository of the ideas about street planting that contributed to the expertise of staff in fashioning a particular type of urban aesthetics found in other places.

As colonial institutions, botanic gardens became one of the centres that moved notions of street form and function into places within the colony. In New South Wales, this was not always a case of dealing with existing city form, as it was in Europe, or India. Instead the settlements of Grafton and other colonial towns and cities were being established in the second half of the nineteenth century. Many 
of the municipalities and councils of New South Wales were only gazetted in the 1880s. Those that had been established earlier did not necessarily include street tree planting at their inception. Such landscaping was more likely to appear once towns were functioning as rural centres. This placed the Sydney Botanic Gardens in a primary position to influence the style of street tree planting.

In 1881, the Sydney Botanic Gardens set up the 22-acre State Nursery on the Bow Bowing Creek at Campbelltown, adding it to the established nursery at the Farm Cove site. These two nurseries, in conjunction with the Gosford State Nursery, were responsible for supplying free seeds and seedlings to councils and municipalities for use as street trees. Local councils could supplement these free trees with stock purchased from local nurserymen. The local nurserymen used the same sorts of trees as those supplied by the nurseries of the Sydney Botanic Gardens. As such, this institution was significant in developing a culture of street trees, how such trees should be used and what plants were best suited to this particular use in urban environments. During the directorships of Charles Moore (1848-1896) and Joseph Maiden (1896-1924) this institution was a place that provided not just stock and seedlings, but developed ideas about how nature's inclusion into urban environments had the capacity to influence and enhance the cultivation of civilised citizens.

\section{Introducing Grafton}

In 1859, 69 householders from the Clarence River area petitioned the New South Wales Government, and the Grafton Shire Council was formed. The first council meeting was held in September of that year ('Gazette notice' 593). One of the first demands on the council took the form of a citizens' petition. Presented to councillors in October, just one short month after the first meeting, they turned to the state of the streets. They proclaimed: 'We the undersigned, now members of the municipality, respectfully beg to memorise the committee on the necessity of cleaning and opening the streets of Grafton for the better convenience of trade and traffic' (Grafton Municipal Council 35). Street trees were not included in this early planning for the town. In fact, the impulse of the council was just the opposite - they slavishly followed the survey lines of the towns by imposing graded surfaces across the landscape. They removed the trees, shrubs, vines and other understory plants locally referred to as 'brush' and replaced them with a grid of empty streets. As the city expanded, new streets of the survey were cleared, rolled and prepared for traffic. As a general rule, when brush was removed this entailed clearing from the ground level and above, creating a grid into which schools, houses and businesses were built. In discussing the petition, 
the council records and celebrates the 'men whose strenuous efforts to remove the dark realities of the old days have made possible the golden opportunities of to-day' (Grafton Municipal Council 35). On the Clarence River it was the brush itself that was threatening. The darkness of the wild natural environment was juxtaposed with the golden opportunities represented by a grid layout of neat streets that tamed and harnessed the land for settlement (Giblett). ${ }^{1}$

The township expanded as closer settlement became a reality in the area. Grazing, which had followed the cedar harvesting, turned to dairying and agricultural pursuits. The social, economic and cultural life of the town grew as the population and wealth of the area expanded (Kass). In the early years of settlement, various languages dominated the aural environment: English, German, Gaelic and the multiple languages of the indigenous residents of the town including those of the local Gumbainggir people (Grafton Municipal Council 17). Each community contributed to the vibrancy of the rural township of Grafton. Photographs reproduced in the council history in 1909 show the thriving commercial centre of the 1870s, though its dusty streets were denuded and bare.

The removal of these trees in the 1860s was to have a positive influence on establishing street trees a decade later. Some trees replicate the canopy size under the ground level in root systems that seek out nutrients and water as well as anchor them in place; other rainforest species are shallow rooting (Clark andMatheny 42-47; Harris 42-47; Bernatsky 25-32). As the early residents transformed the town they grubbed out, burned down, or dug out the remaining core, but there was a residual mass of lateral or deep tap root stock that remained underground (Bradshaw, Hunt and Walmsley); as that material died it was converted, thus enriching the soil, though it can take many years for root-stock to completely break down. When street trees were planted in the 1870s, a series of soft tunnels in the soil, left by this earlier clearing, provided optimal conditions for new root systems to thrive.

In addition, the layers of alluvium deposited through the flood cycles of the river enriched the soil quality of this area. Grafton's location next to the river also influenced the quality of the soil for the growth of trees (McComb andLake 153-62). Lands adjoining the river acted in response to the ground water tables that rose and fell in accordance with the rainfalls in the broader catchment areas of the Clarence Valley. This hydrated the ground, which in turn enhanced the success rates of introducing trees. Combined, all of these ecological factors assisted the establishment of street trees in Grafton. Grafton commenced planting of street trees in the 1870s, at least a decade after the council was

1 See Giblett for an interesting discussion of the negative language used to understand and manage wetlands during this time. 
formed and the brush removal began. This was ample time for the root-stock to rot down. As the streets were trenched and prepared for trees, gardeners would have found soil conditions suitable for this type of planting.

There has always been local conjecture about who planted the first trees and where they were planted: 1869 (Maxted), 1870 (Dockrey), and 1874 (CraigieLaw, vol. 7, 32-35) are all dates given for the first plantings. Some say figs were planted outside the court house ('Back to Grafton' 21) and others say the School of Arts building (Craigie-Law, vol 13, 102). Some say that the Mayor was the first to plant and others attribute that honour to local businessmen, who were supposedly asked to donate a tree each for street planting (Lockley). According to local environmentalist Barbara Fahey, the oldest trees are those in Victoria Street, which also houses the oldest municipal buildings, the post office, the court house and the police barracks. ${ }^{2}$ Regardless, it was clear that this was a project that enjoyed a majority community support.

\section{Phase One: Conformity within Diversity}

Charles Moore began his directorship at the Sydney Botanic Gardens in 1848 under a cloud of confusion. He had been appointed by the colonial office in London to the position at the same time that James Bidwell was appointed by a local committee. Moore's appointment stood and he was to live at the Farm Cove site for 48 years until his retirement in 1896. During this time he consolidated the position of the Sydney Botanic Gardens as both a scientific institution and an important recreational space for the people of Sydney. Under his leadership a herbarium and library were both established, as were links into the transnational networks of botanical exchange. Providing trees for streets was one of the many duties that he performed while the principal employee of this organisation.

In 1874, Moore sent a range of plants to the Public School and the Police Department at Grafton, both early public institutions that requested plants. ${ }^{3}$ 31 trees went to the Police and nineteen went to the school. Planting of trees by children and prisoners of the police department was seen as fulfilling a civic duty. This activity was one that was thought to enhance the capacity for collective citizenship among the community (Hoskins). Katie Holmes, Susan Martin and Kylie Mirmohamadi have mapped the way that public and private gardens and gardening more generally were caught up in a quest to demarcate

2 Guided tour conducted for me by long-time resident, tree committee member and environmental activist Barbara Fahey 7 August 2008.

3 The registers of plants sent away list all the species and quantities of plants sent in the early volumes. In early entries Moore listed the plants, quantities and when they were being sent to botanical institutions, but later reduced the entries to quantities of trees, shrubs and misc. Maiden was to further reduce the entries during his tenure and ceased specific lists for botanical institutions as well. Maiden was much more interested in being able to report volume than particularity. 
healthy life and patriotic citizenry amongst all classes in Australian colonial society, while Benedict Taylor argues that tilling the soil in plantation forestry improved the morality of male prisoners. Working with nature, whether in a prison plantation or a domestic garden, provided a way to connect social behaviour of the individual with the good of the broader community. Local involvement in street plantings was promoted for the same social outcomes. The prison population, along with the children, provided labour for introducing early trees in Grafton, but this was a two way process enabling them to work toward becoming good citizens of the city.

The consignments sent in 1874 provide examples of the types of trees that Moore sent for local use from the nursery at the Farm Cove site. These trees were a mixture of exotic and native. Native stock included pines Araucaria excelsia and A. bidwelli, figs Ficus macrophylla and lilly pillies Eugenia smithii. Exotic did not necessarily equate to plants from Britain or Europe, but also included plants from outside of the British Empire that had also made their way into global circuits of exchange. Some of these trees were the best examples of ornamental street trees used in other places across the world. They included planes, elms, pines and cypresses - all trees used in North America and Europe - but also Camphor Laurel Cinnamomum camphora and Catalpa Catalpa Kaempferi from China, and the Sawara cypress Chamaecyparis pisifera from Japan ('Registers' 82).

In a letter to the editor of the Clarence and Richmond Examiner in 1874, local nursery man Henry Volckers recommended a mixture of trees for shade in the Clarence climate. These included three indigenous species: 'the Turpentine, the Moreton Bay Chestnut and the Moreton Bay fig', and four exotic: 'the White Mulberry, the Weeping Willow, the Camphour Tree and the Plane Tree.' No records exist to identify the exact trees planted into Grafton streets at this time. However the physical remnants of this phase are evident in the living trees in Fitzroy, Prince and Victoria streets. The Court House, the Police Station and the Post Office are all located in these streets. These are the earliest Government buildings and outside these buildings, on these streets, are the oldest street trees. Remnant plantings of camphour laurel, oaks, elms, plane trees and pines still grace the oldest streets of the town, particularly Victoria Street where these civic buildings are located. The early trees flourished due to the local ecological situation combined with a community that cared about the aesthetic of the town. What was distinctive about this phase of the street planting was the variety of trees planted. The trees did not only include trees identified with European towns (planes) but also included trees from China (camphour laurel) and India (figs). Australian trees included local rainforest trees (turpentine), but added rainforest trees from other places (Moreton Bay figs and chestnuts). 
Helen Armstrong singles out the use of rainforest trees for this purpose and links this to the early colonial excitement about the strangeness of the indigenous botany. In addition, she makes the case that figs used in the grid patterns of cantonment areas in British India influenced the introduction of figs into the Australian context (23). This does not, however, account for the variety of trees used in Grafton. On the other hand, Mirmohamadi provides some clues to the phenomenon of mixing native and exotic together when she argues that although domestic Federation gardens (popular a little later), included indigenous plants, these were subsumed into already existing templates of gardens design ('Cultivating' 84). Rainforest trees were adapted to streets in the same way. Trade catalogues of this time did not distinguish plants as native or exotic. Lists of plants were provided on the basis of their use-value. Ornamental trees - for both domestic and public spheres were listed as one category ('Some NSW Plants' 341). Whether a tree was indigenous or exotic or local or from a rainforest was not a consideration in choosing trees for streets. Instead the primary qualifier was their shape. Trees that looked like the street trees of places like Paris, London, Washington and a myriad of other places conformed to a universal idea of an urban aesthetic.

The local community in Grafton preferred a diverse representation of trees for their streetscapes, favouring neither indigenous nor exotic trees, but a combination of the two. The trees grew quickly; photographic evidence from the 1880s demonstrates well-established and healthy trees along the main thoroughfares of the town (Mitchell Library; Clarence River Historical Society). Between 1874 and 1885,1500 trees were planted at a cost of $£ 1,680$. This cost included labour, tools, material for trenching and tree guards, and possibly the purchase of young trees. By this time the population of the town had grown to 4000 , enough to apply to the New South Wales government for an additional ward for the council. The outlay of $£ 1,680$ suggests that the council was able to raise considerable revenue that could be returned to the community in the shape of street trees.

These trees provided shade; an ameliorative to the heat and humidity found in Australia. Street trees were predominantly referred to as shade trees when directors of the Sydney Botanic Gardens publicly discussed this matter ('Some NSW Plants'). This indicated a particular function in a hot climate, where settlers needed protection from the heat of the summer sun. Unlike Europe, where the deciduous tree was coveted for its capacity to allow winter sun to warm the chill of the streets, in many parts of Australia, shade was a local requirement all the year around. When presenting the positive aspects of deciduous trees, Maiden argued:

There is much to be said for deciduous trees in towns. We have the beautiful spectacle of their unfolding leaf buds, then the abundance of 
their shady foliage, and finally we have the bare branches at a time when the sun has least power, and the streets require all the light they can obtain. ('Tree Planting for Shade' 303)

For these reasons the cold climate trees did have a place and were grown by Moore in the nurseries of the Sydney Botanic Gardens.

In 1910, journalist Leslie Curnow visited northern New South Wales and waxed lyrical about the 'trees that line [Grafton's] wonderful streets'. He wrote 'many inland towns have fine trees, Bathurst, for instance, but Grafton ought to be world-famous in this respect' (44-5). The trees that Curnow saw in the streets of Grafton were the South American jacaranda, Jacaranda mimosifolia, the South African cape chestnut Calodendrum capense, the Australian silky oak, Grevillea robusta, the Illawarra flame tree Brachychiton acerifolius, the bunya pine Araucaria Bidwelli, the bean tree Castanospermum australe and the American plane tree, Platanus spp. Additionally, photographic evidence shows the use of the South Asian figs Ficus spp. in Grafton's earlier street plantings. The original decisions made by local council officials about street plantings in Grafton preferred flowering over foliage trees and did not prescribe to native or exotic categories that drove the decision about selection.

Of these, the jacarandas, the cape chestnuts, silky oaks and bean trees all flower in the early summer, when rains are expected in each of their native habitats. Shedding leaves in winter and flowering in spring, this allows seeds to fall in times of high rainfall, thereby ensuring the best chance of healthy germination and early growth. For Grafton, this meant that colour was a feature of the urban aesthetic imagined for the town. Trees such as jacarandas, silky oaks and figs all required the special attention of maintenance crews to attain the sort of density that was usually required. Some of the trees shaded the streets in the hottest months of the year, while the deciduous nature of other trees meant that some of the key streets of Grafton were warmed during winter.

The Australian trees used in Grafton were all trees that would have grown in the local brush and subtropical rainforest stands of the pre-settlement Clarence Valley. Only one generation of local people separated the desire to clear the brush from the introduction of selected species back into the ground at Grafton. Signalling recognition of the irony of this move, one objector to the project said 'We cleared the streets and scrub and you plant them again!' (Craigie-Law 102). Here the trees of a natural habitat, once connoting darkness, were transformed into civilised trees, the bearers of civic pride. Progress was delivered in this form and as the trees aged, the beauty of the town was promoted through the trees ('Grafton City of Trees'). 
Moore contributed to the urban aesthetic of Grafton over the course of the decades between the first wave of street tree planting in the 1870s and 1880s, and the second phase in the 1910s. The Campbelltown nursery supplied trees for consignments to be sent to the Convent of Mercy, the local Lands Office, the Public School, Roman Catholic Church, Church of England Cathedral, Court House, Aborigines Board, the Experimental Farm, Benevolent Society, Goal, Police Station, a park in South Grafton and the hospital ('Registers'). The volume of seedlings sent to these public bodies suggests that perhaps some of these trees were planted into the streets as well as the grounds of places. Local Newspaperman W.A. Zuill reported that 25 Norfolk Island Pines and Bunya Bunyas were planted in Victoria Street by prison labour in 1877. It was apparent that Moore's nurseries at the Sydney Botanic Gardens were not the only source of supply for these early street trees and local nurserymen were also supplying stock to the council. Henry Volckers, Thomas Bawden and E.P. Samson were all advertising the sale of seeds and plants in Grafton during the 1870s (Kass 93).

After the period of prosperity in Grafton that saw the introduction of street trees came a series of environmental occurrences that affected the settlement economy. A drought in 1886 was followed by a series of floods between 1887 and 1893 ('Clarence River Floods). ${ }^{4}$ By that time, a broad-scale depression had hit the larger national economy, impacting on this area through the downturn in export commodity prices. In a city whose civic pride was already bound up with its beautiful trees, this aspect of municipal governance would have in all likelihood required reassessment. During this time the council made use of the free-of-charge stock sent by Moore to continue the ongoing project of planting trees to supplement any purchases made from local nurserymen. In the 1880s he sent 480 trees to the Municipal Council for use in streets and one box of Moreton Bay figs to the Police Department ('Registers' 40, 183, 194, 209, 274). Again in 1895, Moore supplemented local stock with 200 trees for Grafton streets ('Registers' 128). By 1900, locals claimed that 2000 trees grew on Grafton streets; one quarter of them had originated from the Sydney Botanic Gardens.

\section{Phase Two: One Street, One Tree}

In 1896 Charles Moore retired as the Director of the Sydney Botanic Gardens after 48 years of service. The incoming director was no stranger to civic and scientific communities in Australia. Joseph Henry Maiden arrived in Sydney in 1880 and from 1881 until 1896 he was the curator of the Technological Museum. In that post he had established himself as an important authority on Australian botany. His reputation and reach extended far into the transnational botanical

4 According to the Daily Examiner the town flooded on 8 July 1876; 26 January 1887; 10 July 1889; 10 January 1890; 4 February 1890; 12 March 1890; 13 April 1892; 12 February 1893; 19 February 1893; 12 June 1893. 
exchange network, as he with corresponded with colleagues in all the major botanical institutions in the world (Gilbert). When Maiden took up his position as director of the Sydney Botanic Gardens, Grafton was already considered to be a prime example of the impact of trees in civilising rural centres. Maiden was not initiating a new campaign in Grafton, but was simply building upon the structures that were available to him in his new job.

Over the course of Maiden's directorship, he changed the balance of sites which received plants. Early in his term, the dominant recipients of consignments of trees were the public schools. This corresponded with Maiden's support of Arbor Day activities for school children ('Acacia Burkittii'; 'Chat about Wattle'; Robin). Progressively over the years, as his public campaign for street trees gained momentum, the municipalities and councils received the majority of consignments of trees ('Annual Reports'). This corresponds with his growing advocacy in the public arena for the inclusion of street trees in urban planning. Maiden championed this work alongside a commitment to other types of urban landscaping. In the 1909 Royal Commission that examined the ways to improve the city of Sydney, he advocated for a broad range of urban parks, gardens and street plantings. His statements about 'roadside trees' used examples from England, Europe and America to make the case that such planting should be undertaken in New South Wales (Hughes 191). Grafton was also an exemplary Australian case of all the aspects that he championed.

As Maiden's understanding of the ecological requirements of different places in the state evolved he was able to confidently predict the types of trees suitable to different regions. He synthesised this knowledge in a map of New South Wales demarcating zones based on differences in geography. The divisions, which guided his choices of trees sent to a particular area, were based on geology, types of vegetation cover, rainfall and climatic variation. Maiden identified five divisions:

1) The cold region, consisting of the north and south tablelands-here British trees flourish; (2) the coastal strip; (3) the Northern Rivers, a distinctly sub-tropical belt, forming the north-eastern portion of the State; (4) the Western Slopes and Riverina; (5) the Western Plains. ('Tree Planting for Shade' 300)

Maiden gained this knowledge by travelling through New South Wales, and by regularly asking for information from correspondents about the suitability of trees to different areas. When categorising the state into zones, Maiden identified the Grafton area, the Northern Rivers, as geographically distinct. Although no map accompanied his writings about the zones of New South Wales, it may be safe to presume that the area that he is discussing is the area now more formally 
identified as the Northern Rivers region. It covers the country north from Port Macquarie to the Queensland border at the Tweed River, and is bounded to the west by the Great Dividing Range. Grafton sits in the centre.

In 1904 and 1905, Maiden and his botanical collector John Boorman visited the Northern Rivers region, collecting botanical material for use in the work of the Sydney Botanic Gardens ('Annual Report 1903' 6; 'Annual Report 1906' 9). This visit gave Maiden the opportunity to contact local councils and other individuals and bodies who received plants from the Sydney Botanic Gardens. Grafton's fame regarding the street trees would have attracted Maiden and Boorman to the 'city of trees' (Hill). One of the people with whom Maiden developed a corresponding relationship was the nurseryman Henry Volckers. In 1906, Maiden and Volckers exchanged both seeds and living plants ('Annual Report 1906' 8-9). Such was the local appreciation for this relationship between the city scientist and the local entrepreneur that it was recorded in Volckers' obituary as a defining aspect of his notoriety. The paper reported 'Mr Maiden, Government Botanist, looked on Mr Volckers as an authority in matters pertaining to his department and always interviewed him on his visits to the district' ('Obituary').

One of the constraints of Maiden's campaign for street trees was the boundary of his bureaucratic control. While he could readily supply trees through his nurseries and happily gave advice about street plantings, ensuring that trees were appropriately planted and nurtured fell beyond his jurisdiction. Maiden argued that one of the key aspects of the success of local tree planting was the existence of a local gardener, preferably employed by the local council. In this way, trees could be tended within local communities in accordance with the information disseminated by the Sydney Botanic Gardens. Maiden said in 1905:

in Sydney and out of it there still flourishes the ignorant idea that to plant a tree the only thing required is a hole. The first thing necessary is to place such work (as regards the public requirements) in the hands of a professional gardener. ('Tree Planting in City Streets' 6)

Thanks to the combination of serendipity and entrepreneurship, this role was already filled in Grafton by Maiden's correspondent, the seedsman and nursery owner Henry Volckers. According to his friend H.C.T. Maxted, Volckers was settled in Grafton by 1869. He had emigrated from his birthplace of Holstein, Germany, in 1856 to chase gold in Queensland. After a trek through New South Wales (Craigie-Law, Vol 13: 99-104) he and his first wife Elizabeth ended up in Grafton, where he lived until his death in 1911 ('Pioneer Register' 215). Volckers commenced business in Prince Street in 1871 ('Notice'). He initially opened a store and nursery and then expanded to include two other nursery sites. At times he employed up to five men, including a contingent of apprentices, who all lived at the nursery with his wife and family (Graftonian). The nursery 
supplied seeds and plants for a broad range of community needs. They stocked a 'choice collection of fruit and ornamental trees, shrubs, conifers, climbing plants, agricultural, garden and flower seeds' (Volckers Family). This nursery serviced domestic gardens, pastoral homesteads, commercial fruit and vegetable growers, and municipal endeavours to improve the aesthetic of the town. While Maiden acknowledged that local council gardeners would be affected by the seasonal evaporation of work ('Our parks' 5), in Grafton this was managed by contracting work to the Volckers' nursery. One three-year council contract ensured that the trees were cared for, watered, and appropriately pruned until they were properly established - all recommendations advocated by Maiden for success in tree planting (Leaney).

In the first decade of the twentieth century, street tree planting in Grafton underwent a stylistic change. At this time the jacaranda Jacaranda mimosifolia was conferred a primary role amongst the trees in the city. This change in direction, which involved substituting variation for uniformity, aligned with Maiden's preference for avenue planting. In the discussion following George Knibbs lecture on 'The Theory of City Design,' Maiden stated:

let me enunciate an axiom "one avenue one tree." The finest avenues in the world consist of one kind of tree, as by that means uniformity of growth and general appearance, which gives the main charm of an avenue, can alone be secured. (Knibbs 106)

In another forum, The Forest Flora of New South Wales, he pointed to 'the Horse chestnut avenue of Bushey Park, near London, and the Cryptomeria Avenue of Nikko, Japan' as celebrated examples of single species avenue plantings. He went on to argue that 'The mixed avenue is an abomination, ragged and irregular at the best' ('Tree Planting for Shade' 300). Advocacy of single species planting distinguishes Maiden's theories of urban landscaping from those of his predecessor Charles Moore, but also demonstrates his clear understanding of how his views were related to international street tree trends.

In 1910, Volckers' apprentice Alfred Leaney took delivery of a case of eightyfour young jacaranda trees sent by the Sydney seed merchants Anderson \& Co. As a commercial enterprise, Volckers could not have accessed the free supply from the Sydney Botanic Gardens. Anderson \& Co did, however, exchange seeds and living material with the Sydney Botanic Gardens over Maiden's tenure, placing all three bodies in exchange relations with one another (Annual Reports 1896-1924). Volckers followed each of the trends set in the capital city. In the first twenty years of contributing trees to Grafton's street he supplied a mixture of varieties, but from 1910 onward it was the single species, Jacaranda, that Volckers planted and tended in the local community. 
Different species of trees were used in avenue planting across the state of New South Wales. In Bathurst, poplars and elms were favoured. Internationally this trend was followed in Washington where elms were planted, and in Paris planes were the dominant species that lined the streets. Each place developed a preference for a particular tree that could be used in blocks of plantings. The people of Grafton preferred Jacarandas, but there are no definitive records as to why it was these trees that came to dominate the local streetscapes. Maiden certainly endorsed the use of Jacarandas when he said:

Jacaranda mimosaefolia (sic) is a tree with fern-like foliage and beautiful tubular purple blossoms. It is one of the handsomest trees in cultivation. It is semi-deciduous like the silky oak. It is hardy in the coast districts and foothills. ('Tree Planting for Shade' 305)

The earlier planters of trees in Grafton showed a propensity for flowering trees, so perhaps the eighty-four young jacarandas planted and nurtured by Leaney and Volckers on behalf of the council simply followed the model provided by the mature trees already in the streetscapes. If these trees looked beautiful and provided shade then there was no reason to change to another type of tree. It would have been costly to do so and to still expect to create a uniform aesthetic across the city. 84 trees, carefully looked after through the crucial early years established a new look embraced by the people of the city.

The trees of Grafton were no longer seen as indigenous or exotic, but as Australian because of their association with this Australian town. Their national origins were subsumed by the task of nation-building. W.A.B. Greaves, the exCommissioner of Crown Lands and the District Surveyor of Grafton, wrote in 1918: 'These glorious avenues, with their picturesque effects and their variety from street to street, should develop in the same category of Paris, Nice, Naples and Genoa' ('Letter to the editor'). In writing home to his nephew Augustus, H.J. Holt compared the aesthetic effect to the Unter den Linden, the famous avenue of lindens in Berlin, Germany (11). Curnow, though listing the different types of trees that he encountered in 1910, did not see them for their difference; rather, he saw them for the role they played in making Grafton a special Australian city. Locals placed jacarandas and the earlier mixed plantings of Grafton into an aesthetic continuum with these famous European cities.

\section{Conclusion}

Street trees in Grafton, although distinctively local, were also part of a global trend that saw trees introduced into streetscapes on all continents. The Sydney Botanic Gardens was part of each of the two early phases of style. It sent trees to Grafton, and also provided advice and information about successfully maintaining and managing the urban aesthetic of this New South Wales town. 
Through transfer of plants and information, the town and the institution became part of a larger, global campaign for street trees as part of a modern urban aesthetic.

The relationship between the Sydney Botanic Gardens and the local Grafton community relied in part on the serendipity of relationships formed through a common interest in botanical exchanges. The city-based institution was able to provide advice about street planting that was drawn from information collected by staff and the two directors, Joseph Maiden and Charles Moore. However, the role of the nursery at Campbelltown enhanced the possibility of turning these ideas into material culture because they grew the trees that came to be distributed to councils like the one at Grafton. This meant that during Moore's time he could follow a mixed planting regime by sending out a wide variety of trees. Usually this meant sending small numbers of a particular plant, but multiple different species. In Maiden's time, consignments of plants sent for street planting conformed with his ideas of avenue planting-large volumes of single species reinforced a particular aesthetic, which in Grafton was for jacarandas. In this way the Sydney Botanic Gardens directed the form and style of street tree plantings across the state by drawing on the resources available to them from exchanges within the botanical networks that operated across the globe.

This did not mean that Grafton was without agency in this process. On the contrary, without a receptive council, it would not have mattered what the Sydney Botanic Gardens sent from Campbelltown. In Grafton, it was the local community and a local nurseryman that combined with the best of the government efforts to provide attractive streetscapes for rural New South Wales. The people of Grafton had their own ideas about which trees they preferred to beautify their city. This was undoubtedly an international trend, but the local inflection saw jacarandas take a prime place in this urban aesthetic, instead of plane trees or Moreton Bay figs. In 1935, the council inaugurated the Jacaranda Festival which has taken place every November since that year. It should be noted that jacarandas are relatively slow growing. By 1935 the trees planted by Volckers and Meaney in 1910, and those planted before that time, were mature trees, worthy of becoming the symbol for the city. In 1991, John Wrigley conducted a Heritage Tree Survey and found 1457 jacarandas growing on streets all over the city. Jacarandas dominate the urban landscape for a community that still calls Grafton a 'city of trees' (Dockrey). As a result of committed nurturing of this urban aesthetic the festival has always attracted many visitors to the town.

From this time until the 1970s, Grafton's council and community preferred jacarandas for their streets. In Australia there has been a movement back to using native trees in landscaping for an urban aesthetic ('Talking About'; 
Cerwonka103-150). This process no longer includes an input from the Sydney Botanic Gardens. Its role and influence in the introduction of street trees is no longer a part of its institutional work, having sold off the Campelltown nursery site as part of cost saving measures during the 1930s depression. Local Grafton environmentalists are presently advocating for the replacement of all exotic trees, including jacarandas, with a diverse range of native species. This proposal has been actively resisted by other sectors of the Grafton community who see the maintenance and replenishment of jacarandas as an integral part of the ongoing social and economic life of the city. The Jacaranda Festival continues to celebrate the contribution of these trees, first planted in the late nineteenth century, to the making of a unique Grafton identity. Gradually, over a period of one hundred and forty years, the exotic from South America had become Australianised in Grafton.

Dr Jodi Frawley is a Research Associate at University of Technology, Sydney. She is an environmental historian whose research focuses on transnational networks of botanical exchange, in particular, the role of science and scientific institutions in mobilising plants, plant material and plant information, as well as the broader social and cultural impacts of the environmental change that occurred as a result of these exchanges.

\section{Works Cited}

'American Trees for America.' Garden and Forest, no. 513 (1897): 509.

'Clarence River Floods.' Daily Examiner, 9 September 1935.

'Death of H. A. Volckers,' Clarence River Examiner, 24 August 1911.

'Grafton's Railway Problem.' The Commonwealth Home 1926, 13-15.

'Notice H.A. Volkers (Sic).' Clarence and Richmond Examiner, 20 June 1871.

'Roadside Trees.' Garden and Forest, no. 473 (1897): 111.

'Trees and Shrubs for Towns.' Journal of Horticulture and Cottage Gardener (1882).

'Grafton The City of Trees.' Promotional pamphlet, Clarence River Historical Society, item C1349.

'Town Gardening.' Journal of Horticulture and Cottage Gardener. (1867): 27, 18990, 207-8.

'Tree Planting in London.' Journal of Horticulture and Cottage Gardener. (1887): 181. 
'Trees and Shrubs for Towns.' Journal of Horticulture and Cottage Gardener. (1882).

Armstrong, Helen. 'Urban and Rural Avenues in the Australian Landscapes: Origins and Influences.' Landscape Australia 14.2, (1989): 22-26.

Back to Grafton Week. Brisbane: Queensland Soda Fountain Journal Publishing, 1932.

Bernatzky, A. Tree Ecology and Preservation. Amsterdam: Elsevier Scientific Publishing, 1978.

Bradshaw, Anthony and Ben Hunt, and Tim Walmsley. Trees in the Urban Landscape: Principles and Practice. London: E \& FN Spon, 1995.

Cerwonka, Allaine. Native to the Nation: Disciplining Landscapes and Bodies in Australia. Minneapolis: U of Minnesota P, 2004.

Clarence River Historical Society. Photographic collection.

Craigie-Law, Richard. 'Copied manuscript of Mrs Volckers memoirs' in Notebooks and Newspaper Clippings Books, vol.13, Clarence River Historical Society.

-. 'In the Seventies, clipping from the Daily Examiner' in Notebooks and Newspaper Clippings Books, vol.7 Clarence River Historical Society: 32-33.

Curnow, Leslie. 'The Northern Rivers - The City of Grafton.' 27 October 1910, Clipping in Mitchell Library Newspaper Cuttings Vol 20: 44-5.

D. W. 'The Best Trees and Shrubs for Smoky Towns.' The Garden (1912): 602-03.

Desmond, Ray. Kew: The History of the Royal Botanic Gardens. London: Harvill in association with the Royal Botanic Gardens Kew, 1998.

Detroit City. 'Report of the Department of Parks and Boulevards.' Michigan: City of Detroit, 1905-15.

Dockrey, Glenn. Street Trees of Grafton. Grafton: Clarence River Tourism, 2007.

Frawley, Jodi. 'Campaigning for Street Trees, Sydney Botanic Gardens, 1890s to 1920s.' Environment and History 15 (2009): 303-22.

—. 'Rockhampton Botanic Gardens History.' Rockhampton: Rockhampton City Council, 1999.

Freestone, Robert. 'Imagineering the City Beautiful: Parks, Gardens, and Town Planning Thought.' In Planting the Nation, Ed. Georgina Whitehead, Melbourne: Australian Garden History Society, 2001: 159-86. 
Giblett, Rodney James. Postmodern Wetlands: Culture, History, Ecology. Edinburgh: U of Edinburgh P, 1996.

Gilbert, Lionel. The Little Giant: The Life and Work of Joseph Henry Maiden 1859-1925. Sydney: Kardoorair Press in Association with Royal Botanic Gardens, Sydney, 2001.

Grafton Municipal Council. Grafton and District, Its History, Trade and Industries 1859-1909. Sydney: Local Government Publishing Coy, 1909.

Graftonian, 'Contribution to Grafton of Highest Value to City.' Daily Examiner, 15 January 1955.

Greaves, W. A. B. 'Letter to the Editor: Grafton's Trees.' Newspaper Clipping, File B387, Clarence River Historical Society.

Harris, Richard W and James R Clark, and Nelda P Matheny. Arboriculture: Integrated Management of Landscape Trees, Shrubs and Vines. Upper Saddle River, New Jersey: Prentice-Hall, 1999.

Harris, Richard W. Arboriculture: Care of Trees, Shrubs and Vines in the Landscape. Englewood Cliffs, New Jersey: Prentice-Hall, 1983.

Hill, Ernestine. 'Grafton City of Trees.' $A B C$ Weekly. Newspaper clipping held at the Clarence River Historical Society, n.d.

Holmes, Katie and Susan K Martin, Kylie Mirmohamadi. Reading the Garden: The Settlement of Australia. Melbourne: U of Melbourne P, 2008.

Holt, H. J. 'Letter to Augustus Holt, England.' reprinted in CRHS Newsletter no.12, 23 March 1993: 11-12.

Hoskins, Ian. Cultivating the Citizen: Cultural Politics in the Parks and Gardens of Sydney, 1880-1930. PhD Thesis, Department of History, University of Sydney, 1996.

Hughes, Thomas. 'Royal Commission for the Improvement of the City of Sydney and Its Suburbs.' Sydney: New South Wales Parliamentary Papers, 1909.

K.M.H. 'Line of Trees.' Journal of Horticulture and Cottage Gardener (1871): 185.

Kass, Terry. Grafton: Jacaranda City on the Clarence: A History. Grafton: Clarence Valley Council, 2009.

Knibbs, George. 'The Theory of City Design.' Journal and Proceedings of the Royal Society of New South Wales 35 (1901): 62-112. 
Lawrence, Henry. City Trees: A Historical Geography from the Renaissance through to the Nineteenth Century. Charlottesville and London: U of Virginia P, 2006.

Leaney, Alfred. 'Letter from to Daily Examiner.' 8 May 1957, Volckers Family History File, Clarence River Historical Society.

Lockley, J G. 'Who planted the first trees in our Riverside City?' unidentified Newspaper clipping, Volckers family file, Clarence River Historical Society.

Maiden, Joseph. 'Tree Planting in the City Streets.' Sydney Morning Herald, 6 May 1905: 6.

-. 'A Chat About Wattles: An Object-Lesson Written for New South Wales Children.' Agricultural Gazette of New South Wales (1898): 1-3.

-. 'Acacia Burkittii, F.V.M. Burkitt's Wattle.' in The Forest Flora of New South Wales. Sydney: William Applegate Gullick, 1911: 253-60.

-. 'Annual Reports on Botanic Gardens and Domains.' Sydney: Botanic Gardens, Sydney, 1898-1924.

- ' 'Forestry: Some Practical Notes on Forestry Suitable for New South Wales.' New South Wales Agricultural Gazette 16 (1905): 54-63.

-. 'Our Parks: How to Plant and Tend a Tree.' Sydney Morning Herald, 4 May 1907: 5.

-. 'Some New South Wales Plants Worth Cultivating for Shade, Ornamental, and Other Purposes.' New South Wales Agricultural Gazette 8. 6 (1896): 34179.

-. 'Tree Planting for Shade and Ornament in New South Wales with Especial Reference to Municipal Requirements.' in The Forest Flora of New South Wales. Vol 6 Sydney: William Applegate Gullick, 1913-17: 290-308.

Maxted, H. C. T. 'Planting Days Revived.' Daily Examiner, 23 December 1929.

McComb, A. J. and P. S. Lake. Australian Wetlands. North Ryde, N.S.W.: Angus \& Robertson, 1990.

McCracken, Donal and Eileen McCracken. The Way to Kirstenbosch. Pretoria: National Botanic Gardens, 1988.

Mirmohamadi, Kylie. 'Talking About Native Plants ...' Colloquy text theory critique 12 (2006): 91-102. 
-. 'Cultivating the Australian Gardener: Native Plants and Victorian State School Gardens in the Federation Era,' Australian Cultural History, 26, (2006): 81-98.

Mitchell Library. Small Pictures Collections, Grafton.

New South Wales Government. New South Wales Government Gazette. 10 March, 1859.

Pre 1900 Clarence River Pioneer Register, Grafton: Clarence River Historical Society Inc.

Robin, Libby. 'Nationalising Nature: Wattle Days in Australia.' Journal of Australian Studies 73 (2002): 5-22.

Royal Botanic Gardens Sydney. Register of Plants Sent Away 1870-1913. SRNSW 19/17199, 19/17204-17207.

Solotaroff, William. Shade-Trees in Towns and Cities: Their Selection, Planting and Care as Applied to the Art of Street Decorations: Their Diseases and Remedies; Their Municipal Control and Supervision. New York: John Wiley and Sons, 1911.

Spencer, Roger. 'Fashions in Street Tree Planting in Victoria.' Landscape Australia 4 (1986): 305-309.

State Records New South Wales. 'Municipality of Grafton (1859-1939), Organisational Details.' State Records of New South Wales 2008. <http:// investigator.records.nsw.gov.au/Entity.aspx?Path $=\backslash$ Organisation $\backslash 68>$ Accessed 29 July 2008.

Taylor, Benedict. 'Trees of Gold and Men Made Good? Grand Visions and Early Experiments in Penal Forestry in New South Wales, 1913-1938.' Environment and History 14 (2008): 545-62.

Trees file, Clarence River Historical Society.

Volckers Family File. Newspaper clipping 25 May 1875. Clarence River Historical Society.

Volckers, H A. 'Trees and Shrubs suitable for the Clarence Climate' Clarence and Richmond Examiner, 21 April 1874.

Wrigley, John. 'Grafton Heritage Tree Survey.' Grafton: Grafton City Council, 1991.

Zuill, W A. 'In 1877.' Daily Examiner 1931. 